Vol. 10(3), pp. 58-67, March 2016

DOI: 10.5897/AJPS2015.1385

Article Number: 200264357888

ISSN 1996-0824

Copyright (C) 2016

Author(s) retain the copyright of this article

http://www.academicjournals.org/AJPS

\title{
A DNA-barcode for Melia volkensii Gürke (Meliaceae) and its phylogenetic relationship with some economically important relatives
}

\author{
Eliud S. Mulanda ${ }^{1 \star}$, Ryan M. Awori ${ }^{1}$, Yeremiah Chuhila ${ }^{2}$, Mark O. Adero ${ }^{1}$, Nelson 0. \\ Amugune ${ }^{1}$, Elijah Akunda ${ }^{1}$ and Jenesio I. Kinyamario ${ }^{1}$ \\ ${ }^{1}$ Molecular Biology Lab, School of Biological Sciences, University of Nairobi, P.O Box 30197-00100 Nairobi, Kenya. \\ ${ }^{2}$ Department of Zoology and Wildlife Conservation, College of Natural and Applied Sciences, University of Dar es \\ Salaam, P.O. Box 35064 Dar es Salaam, Tanzania.
}

Received 31 December, 2015; Accepted 1 March, 2016

\begin{abstract}
The study reports the first DNA-barcode and molecular phylogeny of the East African endemic tree species Melia volkensii using the standard two-locus plant barcoding genes ( $r b c L$ and matK). The two genes were amplified and the PCR products sequenced. Complete coding sequences were obtained for both genes. The edited and aligned sequences had lengths of $1371 \mathrm{bp}$ for $r b c L$ and 1524 bp for matK. These DNA sequences were deposited into the DNA Data Bank of Japan (DDBJ) with cross-listing in the European Molecular Biology Labaratory (EMBL) and GenBank databases. The deposited gene sequences were then subjected to separate nucleotide BLASTs in NCBI's GenBank database. Out of 100 Blast results in which the query $(M$. volkensii) had 96-100 percentage similarity in nucleotide sequence for the $r b c L$ gene and $90-100 \%$ similarity for the matK gene, only 16 taxa had data for both $r b c L$ and matK genes. These 16 taxa were used for the phylogenetic analysis and comprised of 6,9 and 1 taxa respectively from the families Meliaceae, Simaroubaceae and Rutaceae. The barcode allowed adequate discrimination of the taxa into their respective generic and species clades. Availability of a barcode for $M$. volkensii will ease identification of the species, provide more robust phylogenetic reconstructions and allow for better tracking of its exotic dispersal.
\end{abstract}

Key words: DNA barcoding, matK, rbcL, DDBJ/EMBL/NCBI Gene Databases, Melia volkensii, phylogeny.

\section{INTRODUCTION}

Melia volkensii (Gurke) is a hardwood tree species of high economic, ecological and germplasm value. It is endemic to the arid and semi-arid lands of East Africa and belongs to the mahogany family, Meliaceae (Orwa et al., 2009). Other members of the family known for their significant timber, pharmaceutical and conservation value

*Corresponding author. E-mail: emulanda123@yahoo.com.

Author(s) agree that this article remains permanently open access under the terms of the Creative Commons Attribution License 4.0 International License 
are Azadirachta indica A. Juss. (Neem), Melia azedarach L. (Purple Lilac), Swietenia macrophylla (Big-leaf mahogany) and the Khaya species.

The primary objective of the study was to develop a DNA barcode sequence for $M$. volkensii. DNA barcoding is the use of nucleotide diversity within a short standardised region of DNA for identification of species (Hebert et al., 2003; Kuzmina et al., 2012; Vijayan and Tsou, 2015). DNA barcoding provides an automated species identification system that is quicker and more reliable than traditional taxonomic methods which rely on morphological characters (Newmaster and Ragupathy, 2009). DNA barcodes can not only resolve phylogenies of plant taxa but are also useful in ecological forensics such as the tracking of illegal trade in plant products (Kress et al., 2015). Other applications of a DNA barcode include monitoring of exotic dispersion, conservation impact assessments, authentication of parts used in preparation of herbal medicine and botanical pesticides, such as tree barks, fruits and leaves (Ferri et al., 2008; 2015; Kritpetcharat et al., 2011; Mankga et al., 2013; Mishra et al., 2016).

Until recently, DNA barcoding of plants was hampered by the lack of a standard region of DNA with sufficient universality, sequence quality and species discrimination power (Hollingsworth et al., 2011). The long search for a universal plant barcode culminated in the adoption of a two-locus barcode consisting of the phylogenetically conserved gene for the large subunit of the chloroplast enzyme ribulose-1,5-bisphosphate carboxylase/ oxygenase (rubisco), also known as $r b c \mathrm{~L}$, and the more rapidly evolving chloroplast gene for maturase $\mathrm{K}$ (matk) (Kress et al., 2009). The 2-locus combination of $r b c \mathrm{~L}$ and matK genes was adopted by the Consortium for the Barcode of Life Plant Working Group (CBOL, 2009) as the standard or core barcode for land plants.

The $r b c \mathrm{~L}$ gene is a chloroplast gene of approximately $1400 \mathrm{bp}$ that codes for the large subunit of rubisco, the enzyme that catalyzes carbon dioxide fixation in chloroplasts. The matK gene, approximately $1500 \mathrm{bp}$, is located within a 2,400 bp group II intron of the chloroplast trnK gene which codes for the transfer RNA for lysine (Johnson and Soltis, 1994; Vogel et al., 1997; Steane, 2005; Hausner et al., 2006; Barthet and Hilu, 2007). It codes for maturase $\mathrm{K}$, an enzymatic protein that allows the intron to remove itself for the two exons of the trnK gene to be spliced together.

A secondary objective of the study was to use the novel barcode sequences in a preliminary phylogenetic study of the Meliaceae and related families. A molecular phylogeny based on DNA barcoding could clarify evolutionary relationships between both the well-known and lesser known members of the family.

This study reports the first DNA barcode for Melia volkensii. The availability of such a barcode for the species is will enable faster and accurate identification of the species and a more robust reconstruction of phylogenetic relationships in the family. This will provide insights on the phylogenetic affinities between $M$. volkensii, well-known members of the family such as $A$. indica, $M$. azederach and S. macrophylla and the lesser known ones. Phylogenetic affinities at the family and generic levels could also reveal closely related families and genera for novel bio-prospecting for compounds of pharmaceutical and pesticidal importance similar to those found in some members of the Meliaceae.

\section{MATERIALS AND METHODS}

\section{Plant materials and DNA extraction}

DNA was extracted from shoot tips of $20 \mathrm{M}$. volkensii seedlings obtained from seeds collected from Mavuria provenance in Mbeere, Embu county, Eastern Kenya (Geo-reference $0^{\circ} 46.379$ 'S, $37^{\circ}$ 39.308'E). DNA Extraction was done using the Cetyltrimethylammonium bromide (CTAB) method of Doyle and Doyle (1987), with slight modifications, which were addition of $10 \%$ sodium dodecyl sulphate to extraction buffer, centrifugation at $16,000 \mathrm{~g}$ instead of $6,000 \mathrm{~g}$ and washing of the DNA pellet with $70 \%$ ethanol instead of a mixture of $76 \%$ ethanol and $10 \mathrm{mM}$ ammonium acetate.

\section{Molecular methods}

M. volkensii complete coding sequence for ribulose-1,5carboxylase/oxygenase (rubisco) large subunit chloroplast gene ( $r b c L)$ was amplified by the PCR method. The expected fragment size was 1397bp (Fazekas et al., 2012). The primers used for rbcL gene were rbclFayf (5'TCCTTTTAGTAAAAGATTGGGCCGAG3') and rbclFayr (5'ATGTCACCACAAACAGAAACTAAAGC3') (Fay et al., 1998). Primers were synthesised by Inqaba Biotec, South Africa. The reaction mixture contained 1 unit of MyTaq ${ }^{\circledR}$ DNA polymerase (Bioline, USA), 1x Mytaq buffer ${ }^{\circledR}$ (Bioline, USA) containing $3 \mathrm{mM} \mathrm{MgCl}_{2}$ and $2 \mathrm{mM}$ dNTPs; $0.4 \mu \mathrm{M}$ forward and reverse primers, $1 \mu \mathrm{l}$ of DNA template and brought to the total volume of $25 \mu \mathrm{l}$ with nuclease-free water. Amplification was done on a MJ Research PTC-100 USA thermal cycler with the following conditions; initial denaturation at $95^{\circ} \mathrm{C}$ for $1 \mathrm{~min}, 40$ cycles of at $95^{\circ} \mathrm{C}$ for $15 \mathrm{~s}$ (denaturation), $55^{\circ} \mathrm{C}$ for $15 \mathrm{~s}$ (annealing), $72^{\circ} \mathrm{C}$ for 1 min $30 \mathrm{~s}$ (extension), and a final extension at $72^{\circ} \mathrm{C}$ for $7 \mathrm{~min}$.

Isolation of $M$. volkensii maturase-K chloroplast gene (matK) was also carried out in a $25 \mu \mathrm{l}$ volume reaction. The expected fragment size was 1500 bp (Fazekas et al., 2012). The primers used were Matk $1 f$ (5'ACTGTATCGCACTATGTATCA3') and Matk1r (5'GAACTAGTCGGATGGAGTAG3'), also sourced from Inqaba Biotec South Africa. The reaction mixture contained 1 unit of MyTaq ${ }^{\circledR}$ DNA polymerase (Bioline, USA); 1x Mytaq $^{\circledR}$ buffer (Bioline, USA) containing $3 \mathrm{mM} \mathrm{MgCl}_{2}$ and $2 \mathrm{mM}$ dNTPs; $0.4 \mu \mathrm{M}$ of forward and reverse primers, $1 \mu \mathrm{l}$ of DNA template and brought to the total volume of $25 \mu \mathrm{l}$ with nuclease-free water. Amplification was done on a MJ Research PTC-100 USA thermal cycler with conditions set at $95^{\circ} \mathrm{C}$ for $1 \mathrm{~min}, 20$ cycles of $95^{\circ} \mathrm{C}$ for $15 \mathrm{~s}, 45^{\circ} \mathrm{C}$ for $15 \mathrm{~s}, 72^{\circ} \mathrm{C}$ for $1.5 \mathrm{~min}$, followed by another 20 of cycles of $95^{\circ} \mathrm{C}$ for $15 \mathrm{~s}, 55^{\circ} \mathrm{C}$ for $15 \mathrm{~s}, 72^{\circ} \mathrm{C}$ for $1.5 \mathrm{~min}$ and a final extension at $72^{\circ} \mathrm{C}$ for $5 \mathrm{~min}$. PCR products were purified with EXO/SAP Amplicon purification kit (Affymetrix, Santa Clara, USA). Purified PCR products were sequenced by Inqaba Biotec South Africa using The BigDye Terminator v3.1 Cycle Sequencing Kit (Applied Biosystems,USA) with ABI Prism 377 DNA sequencer (Applied Biosystems,USA). The same primers used for the PCR reactions were used in sequencing 
reactions.

\section{Database deposition and phylogenetic reconstruction}

M. volkensii rbcL and matK novel sequences were checked for quality and ambiguous nucleotides resolved in MEGA6 software suite (Tamura et al., 2013). Identical sequences were obtained for each gene. Processed sequences of the two genes were deposited in the DDBJ/EMBL/GenBank databases. They were assigned the following accession numbers: LC075516 for rbcL and LC075517 for matK.

The sequences were then used to carry out two separate GeneBank nucleotide BLASTs. The first set of 100 Blast hits gave 96-100 percentage similarity in nucleotide sequence for the rbcL gene and $90-100 \%$ similarity for the matK gene between the query (M. volkensii) and the respective Genbank sequences of members of Meliaceae, Simaroubaceae and Rutaceae families. However, retrieved taxa having sequence data for both $\mathrm{rbcL}$ and matK genes were only 16 , with the rest of the taxa having data for either rbcL or matK. Since the study intended to use both the barcoding genes separately and after concatenation, phylogenetic reconstruction was limited to the sequences of these 16 taxa. Sequence names, database codes, accession numbers, native distribution and uses of the selected species are listed in Table 1.

The retrieved database sequences were also checked for quality and ambiguous nucleotides resolved in MEGA6 software suite (Tamura et al., 2013). Multiple sequence alignments were performed in MEGA6 software suite using the MUSCLE algorithm (Edgar, 2004) and the aligned sequences used for phylogenetic reconstruction. The evolutionary history was inferred using the maximum likelihood method based on the General Time Reversible (GTR) model (Nei and Kumar, 2000). Initial trees for the heuristic search were obtained automatically by applying Neighbour-Join and BioNJ algorithms to a matrix of pair-wise distances estimated using the Maximum Composite Likelihood (MCL) approach, and then selecting the topology with superior log likelihood value. The tree with the highest log likelihood was selected. A total of 1000 bootstrap replicates were performed (Felsenstein, 1985). Phylogenetic trees were edited in FigTree 1.4 (Rambaut, 2012).

\section{RESULTS AND DISCUSSION}

PCR amplification was $100 \%$ successful for both genes. Gel electrophoresis gave highly resolved bands of $\approx 1400$ $\mathrm{bp}$ for $r b c L$ and $\approx 1500 \mathrm{bp}$ for matK, as expected (Figure 1). Sequencing success was $95 \%$ for both genes, with edited sequence lengths of $1371 \mathrm{bp}$ for the $r b c \mathrm{~L}$ gene and $1524 \mathrm{bp}$ for matK. These sequences were successfully deposited in the DDBJ/EMBL/GenBank databases and assigned the accession numbers LC075516 (rbcL) and LC075517 (matK). To the best of our knowledge, they are the first barcode deposits for $M$. volkensii in these databases.

The BLASTs retrieved taxa belonging to three families: Meliaceae, Simaroubaceae and Rutaceae. This is in agreement with previous reports about the taxonomic proximity of these families (Wiart, 2006). However, most of the taxa had sequence data for either rbcL or matK but not both. Therefore analysis was limited to the 16 closely related taxa which had sequences for both the $r b c L$ and matk genes. These consisted of 6 members of the
Meliaceae family, 9 members of Simaroubaceae and 1 member of Rutaceae (Table 1). Consequently, phylogenetic reconstruction was severely constrained by the limited nature of the data retrieved from the databases. A more comprehensive molecular phylogeny of the Meliaceae will be possible only when more sequence data becomes available in these databases. Since the family Meliaceae consists of an estimated 51 genera and 550 species (Wiart, 2006), there is a vast scope for an expanded molecular phylogeny of the family.

The taxa included in the phylogenetic analysis had sequence percentage alignment scores of $96-99 \%$ for rbcL gene and $90-95 \%$ for the matK gene (Table 1). This is in agreement with previous reports of higher discrimination power of matK over rbc $\mathrm{L}$ for most plants ( $\mathrm{Li}$ et al., 2011). This difference was also evident in the pairwise distance matrices (Tables 2 and 3 ) and phylogenetic trees (Figures 2 and 3), with matK giving larger genetic distances between the species than $r b c \mathrm{~L}$ and the concatenated rbcL + matK code giving intermediate distances (Table 4). This was expected as the matK gene is reported to have a higher rate of mutation than the $r b c \mathrm{~L}$ gene (Kress et al., 2009) and is thus more likely to reveal a greater amount of variation between species. The $r b c L$ locus is generally more suitable for determination of evolutionary relationships at the generic level and above (Kress et al., 2005). On the other hand matK has been more successful in resolving species relationships in several families (Johnson and Soltis, 1994; Hilu and Liang, 1997; Rohwer, 2000).

All the phylogenetic trees obtained with separate $r b c L$, matK sequences and with concatenated rbcL + matK sequences correctly resolved the 17 taxa into their respective familial clades with $100 \%$ bootstrap support (Figures 2, 3 and 4). In each family, the vast majority of branches also had high bootstrap values (>90\%). These barcoding genes also allowed adequate discrimination at generic and species levels, as seen in the clear resolution of the genus Melia ( $M$. volkensii and $M$. azederach), genus Swietenia ( $S$. macrophylla and $S$. mahogany), genus Picrasma ( $P$. javanica and $P$. quassioides) and genus Ailanthus ( $A$. integrifolia, $A$. altissima and $A$. triphysa). This suggests a possible use of the two barcoding genes, with additional empirical testing, in resolving taxa in the Meliaceae and related families up to the species level. This recommendation is supported by the findings of Kress et al. (2005) which showed that full-length sequences $(>1 \mathrm{~kb})$ of either gene can give enough sequence length to discriminate between species. The sequences obtained in this study were longer than $1 \mathrm{~kb}$ and therefore met this criterion.

Despite the limited number of taxa used, the molecular phylogeny obtained in this study provides some useful insights into the evolutionary relationships between $M$. volkensii and the taxa that were included in the phylogeny. This is one of the suggested applications of a DNA barcode (Kress et al., 2015). The M. volkensii 
Table 1. Species information and nucleotide BLAST alignment scores for Melia volkensii (DDBJ LC075516.1 and LC075517.1) and selected species.

\begin{tabular}{|c|c|c|c|c|c|c|c|c|}
\hline \multirow[t]{2}{*}{ Family } & \multirow[t]{2}{*}{$\begin{array}{l}\text { Species name } \\
\text { (Common name) }\end{array}$} & \multirow[t]{2}{*}{ Native distribution } & \multirow{2}{*}{\multicolumn{2}{|c|}{ Main uses }} & \multicolumn{2}{|c|}{$\begin{array}{c}\text { Similarity } \\
\text { With } M . \\
\text { volkensii }(\%)\end{array}$} & \multicolumn{2}{|c|}{$\begin{array}{l}\text { Database/ Accession } \\
\text { number }\end{array}$} \\
\hline & & & & & $r b c \mathrm{~L}$ & matK & $r b c L$ & matK \\
\hline \multirow{6}{*}{ Meliaceae } & Melia azederach L. (Purple lilac) & Indian subcontinent and South East Asia & $\begin{array}{l}\text { Timber, medicinal, } \\
\text { ornamental }\end{array}$ & insecticidal, & 99 & 99 & GB/AY128234.1 & GB/EF489117.1 \\
\hline & Azadirachta indica A. Juss. (Neem) & Indian subcontinent and South East Asia & $\begin{array}{l}\text { Timber, medicinal, } \\
\text { ornamental }\end{array}$ & insecticidal, & 99 & 97 & GB/AY128214.1 & GB/EF489115.1 \\
\hline & $\begin{array}{l}\text { Toona sinensis (A.Juss.) M. Roem } \\
\text { (Chinese mahogany) }\end{array}$ & Eastern and South Eastern Asia & \multicolumn{2}{|c|}{ Timber, medicinal, ornamental } & 97 & 94 & EMB/FN599468.1 & GB/JN680341.1 \\
\hline & $\begin{array}{l}\text { Swietenia macrophylla King. } \\
\text { (Honduran mahogany) }\end{array}$ & Mexico and South America & \multicolumn{2}{|c|}{ Timber, medicinal, ornamental } & 97 & 93 & GB/U39080.2 & GB/EF489114.1 \\
\hline & $\begin{array}{l}\text { Swietenia mahogany (L.) Jacq. } \\
\text { (West Indies mahogany) }\end{array}$ & Caribbean Islands and USA & \multicolumn{2}{|c|}{ Timber, medicinal, ornamental } & 97 & 93 & EMB/FN599465.1 & GB/EU042835.1 \\
\hline & Cipadessa baccifera (Roth) Miq. & India, Sri Lanka, Myanmar, China, Malaysia & \multicolumn{2}{|l|}{ Medicinal } & 96 & 94 & GB/AY128225.1 & GB/EF489116.1 \\
\hline \multirow{9}{*}{ Simaroubaceae } & $\begin{array}{l}\text { Ailanthus integrifolia Lam. } \\
\text { (White Siris) }\end{array}$ & $\begin{array}{l}\text { India, Indonesia, Malaysia, Papua New } \\
\text { Guinea }\end{array}$ & \multicolumn{2}{|l|}{ Timber, Medicinal } & 96 & 91 & GB/EU042981.2 & $\mathrm{GB} / 042843.1$ \\
\hline & $\begin{array}{l}\text { Ailanthus altissima (Mill. Swingle; } \\
\text { (Tree of Heaven) }\end{array}$ & China and Taiwan & \multicolumn{2}{|c|}{ Timber, Medicinal, Ornamental } & 96 & 91 & GB/KM360619.1 & EMB/FM179922.1 \\
\hline & $\begin{array}{l}\text { Ailanthus triphysa (Dennst.) Alston } \\
\text { (White Siris) }\end{array}$ & India, Myanmar, Nepal & \multicolumn{2}{|c|}{ Timber, Medicinal, Ornamental } & 96 & 91 & GB/EU042982.1 & GB/EU042844.1 \\
\hline & Castela retusa Liebm.; & Mexico and Central America & \multicolumn{2}{|l|}{ Medicinal } & 96 & 90 & GB/EU042992.1 & GB/EU042854.1 \\
\hline & $\begin{array}{l}\text { Picrasma quassioides } \\
\text { Benn. (Quassia wood) }\end{array}$ & Eastern and South America; East Asia & \multicolumn{2}{|c|}{ Timber, Medicinal, Insecticidal } & 96 & 91 & GB/EU043008.1 & GB/EU042870.1 \\
\hline & Picrasma javanica Blume & India, Bangladesh, Java, Burma, Malaysia & \multicolumn{2}{|l|}{ Timber, Medicinal } & 96 & 91 & GB/EU043011.1 & GB/EU042873.1 \\
\hline & Nothospondias staudtii Engl. & West Africa and the DR Congo & \multicolumn{2}{|l|}{ Timber, Medicinal } & 96 & 91 & GB/EU043004.1 & GB/EU042866.1 \\
\hline & Holocantha emoryi A. Gray & South western USA & \multicolumn{2}{|l|}{ Medicinal } & 96 & 91 & GB/EU043002.1 & GB/EU042864.1 \\
\hline & Hannoa klaineana Pierre and Engl. & West and Central Africa & \multicolumn{2}{|l|}{ Timber, Medicinal } & 96 & 90 & GB/EU042999.1 & GB/EU042861.1 \\
\hline Rutaceae & $\begin{array}{l}\text { Choisya ternata Kunth } \\
\text { (Mexican Orange) }\end{array}$ & Mexico & \multicolumn{2}{|l|}{ Ornamental, Medicinal } & 96 & 91 & GB/KM360716.1 & GB/EF489104.1 \\
\hline
\end{tabular}

barcode could also be useful in aiding identification of the species and its products, enabling more detailed phylogenetic reconstructions and the tracking of its exotic dispersion. However, for application of the matK $+r b c L p l a n t$ barcode in a more comprehensive study of the Meliaceae, there is an urgent need for sequencing of the $r b c \mathrm{~L}$ and matk genes for all the estimated 550 species of the Meliaceae and deposition of the data 


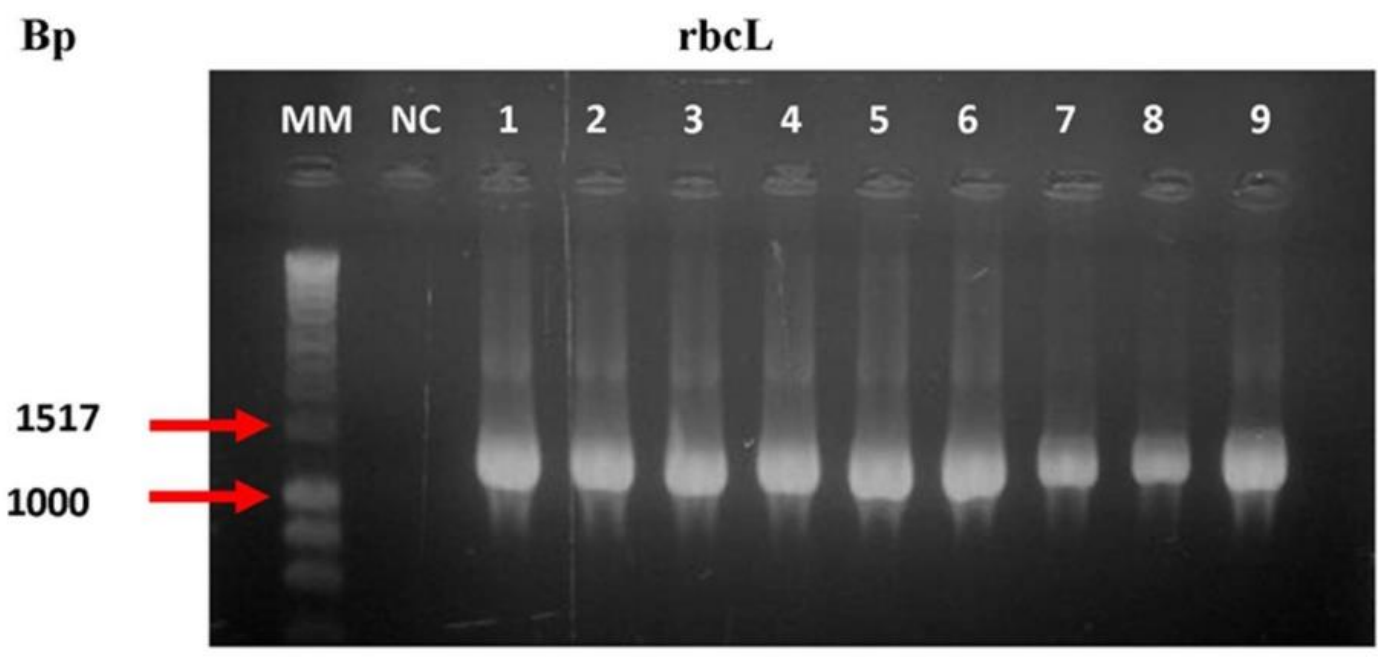

Bp matK

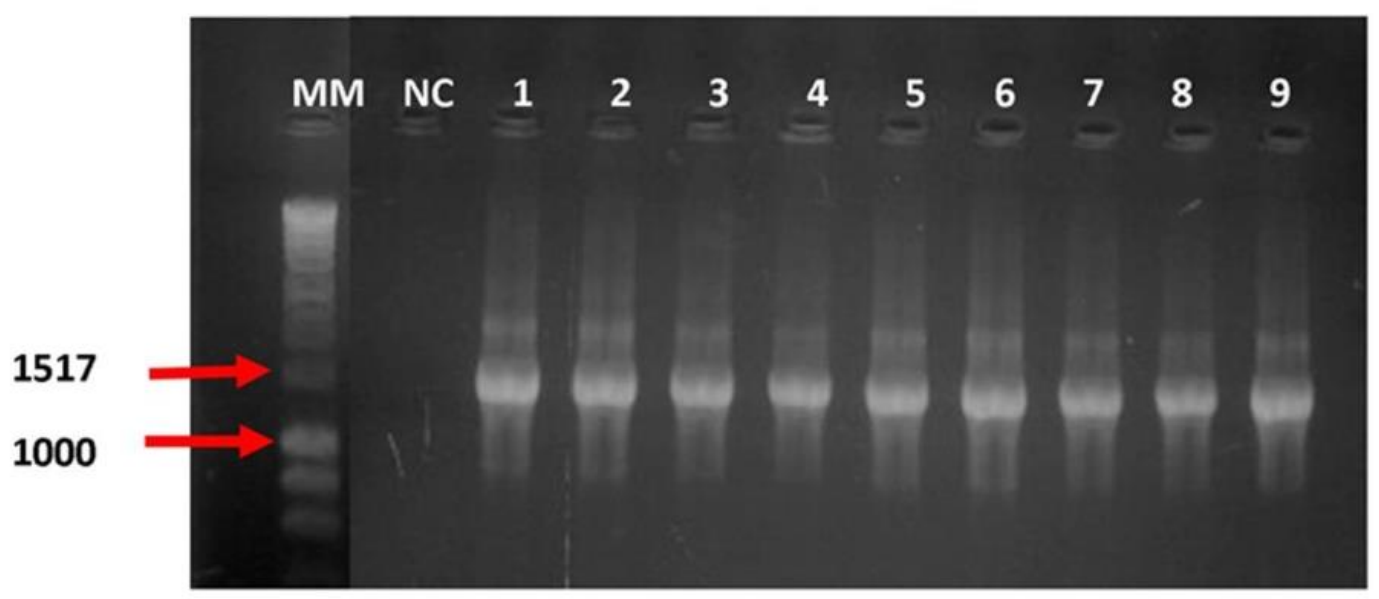

Figure 1. Agarose gel profiles of the isolated chloroplast $r b c \mathrm{~L}$ and matK genes. $\mathrm{MM}=1 \mathrm{~kb}$ ladder, $\mathrm{NC}=$ negative control, $1-9=$ some of the DNA samples used.

in DNA Databases.

\section{Conclusions and recommendations}

The plant barcoding genes $r b c \mathrm{~L}$ and matK managed to resolve selected taxa up to the species level. A partial molecular phylogeny of the Meliaceae and closely related famlilies was obtained. The main limiting factor was the lack of complete data on $r b c L$ and matK sequences in the DNA repositories for members of these families. This calls for accelerated deposition of more sequence data in order to fill the huge gaps in the DNA libraries. Such data can also be used in future Bayesian inferences.

\section{Conflict of interest}

The authors have not declared any conflict of interests.

\section{Acknowledgements}

The authors are grateful to the Kenya National Commission for Science, Technology and Innovation (NACOSTI) for the Research Grant provided to the first author. We are also indebted to Mr. Micheni Ndii and Mr. Patrick Wachira of the Molecular Biology Lab, School of Biological Sciences, University of Nairobi for their technical support. 


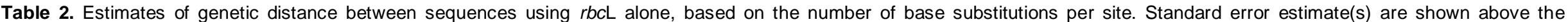
diagonal and were obtained by a bootstrap procedure (1000 replicates).

\begin{tabular}{|c|c|c|c|c|c|c|c|c|c|c|c|c|c|c|c|c|c|c|}
\hline & & \multicolumn{17}{|c|}{ Rubisco (rbcL) } \\
\hline & & 1 & 2 & 3 & 4 & 5 & 6 & 7 & 8 & 9 & 10 & 11 & 12 & 13 & 14 & 15 & 16 & 17 \\
\hline 1 & Melia_volkensii_\{Meliaceae\} & & 0.002 & 0.003 & 0.005 & 0.005 & 0.005 & 0.005 & 0.005 & 0.006 & 0.005 & 0.006 & 0.006 & 0.005 & 0.006 & 0.006 & 0.006 & 0.006 \\
\hline 2 & Melia_azedarach_\{Meliaceae\} & 0.004 & & 0.003 & 0.005 & 0.005 & 0.005 & 0.005 & 0.005 & 0.005 & 0.005 & 0.005 & 0.005 & 0.005 & 0.005 & 0.005 & 0.006 & 0.005 \\
\hline 3 & Azadirachta_indica_\{Meliaceae\} & 0.013 & 0.012 & & 0.004 & 0.004 & 0.005 & 0.005 & 0.005 & 0.006 & 0.005 & 0.005 & 0.005 & 0.005 & 0.006 & 0.005 & 0.006 & 0.005 \\
\hline 4 & Swietenia_macrophylla_\{Meliaceae\} & 0.029 & 0.028 & 0.024 & & 0.002 & 0.001 & 0.004 & 0.004 & 0.005 & 0.004 & 0.005 & 0.005 & 0.004 & 0.005 & 0.005 & 0.006 & 0.005 \\
\hline 5 & Toona_sinensis_\{Meliaceae\} & 0.026 & 0.027 & 0.023 & 0.007 & & 0.002 & 0.004 & 0.004 & 0.005 & 0.005 & 0.004 & 0.005 & 0.004 & 0.005 & 0.005 & 0.005 & 0.005 \\
\hline 6 & Swietenia_mahagoni_\{Meliaceae\} & 0.029 & 0.030 & 0.027 & 0.003 & 0.006 & & 0.004 & 0.004 & 0.005 & 0.005 & 0.005 & 0.005 & 0.005 & 0.005 & 0.005 & 0.005 & 0.005 \\
\hline 7 & Picrasma_quassioides_\{Simaroubaceae\} & 0.037 & 0.037 & 0.034 & 0.027 & 0.025 & 0.027 & & 0.001 & 0.004 & 0.005 & 0.004 & 0.004 & 0.004 & 0.004 & 0.004 & 0.006 & 0.004 \\
\hline 8 & Picrasma_javanica_\{Simaroubaceae $\}$ & 0.037 & 0.038 & 0.034 & 0.026 & 0.024 & 0.027 & 0.003 & & 0.004 & 0.005 & 0.004 & 0.004 & 0.004 & 0.004 & 0.004 & 0.006 & 0.004 \\
\hline 9 & Castela_retusa_\{Simaroubaceae\} & 0.039 & 0.040 & 0.040 & 0.032 & 0.030 & 0.032 & 0.022 & 0.023 & & 0.006 & 0.005 & 0.005 & 0.005 & 0.003 & 0.005 & 0.007 & 0.005 \\
\hline 10 & Choisya_ternata_\{Rutaceae $\}$ & 0.041 & 0.040 & 0.038 & 0.028 & 0.030 & 0.031 & 0.034 & 0.034 & 0.039 & & 0.005 & 0.005 & 0.005 & 0.006 & 0.005 & 0.006 & 0.005 \\
\hline 11 & Ailanthus_integrifolia_\{Simaroubaceae\} & 0.040 & 0.040 & 0.037 & 0.031 & 0.030 & 0.032 & 0.023 & 0.023 & 0.027 & 0.037 & & 0.002 & 0.003 & 0.005 & 0.002 & 0.006 & 0.004 \\
\hline 12 & Ailanthus_altissima_\{Simaroubaceae $\}$ & 0.040 & 0.041 & 0.038 & 0.033 & 0.031 & 0.034 & 0.023 & 0.024 & 0.029 & 0.038 & 0.004 & & 0.003 & 0.005 & 0.002 & 0.006 & 0.004 \\
\hline 13 & Nothospondias_staudtii_\{Simaroubaceae\} & 0.041 & 0.040 & 0.035 & 0.030 & 0.030 & 0.033 & 0.023 & 0.025 & 0.028 & 0.039 & 0.017 & 0.017 & & 0.005 & 0.004 & 0.006 & 0.003 \\
\hline 14 & Holacantha_emoryi_\{Simaroubaceae\} & 0.042 & 0.040 & 0.040 & 0.033 & 0.032 & 0.034 & 0.024 & 0.027 & 0.009 & 0.041 & 0.029 & 0.028 & 0.028 & & 0.005 & 0.007 & 0.005 \\
\hline 15 & Ailanthus_triphysa_\{Simaroubaceae\} & 0.042 & 0.043 & 0.040 & 0.034 & 0.033 & 0.034 & 0.024 & 0.026 & 0.030 & 0.039 & 0.004 & 0.006 & 0.019 & 0.030 & & 0.007 & 0.004 \\
\hline 16 & Cipadessa_baccifera_\{Meliaceae\} & 0.043 & 0.044 & 0.039 & 0.037 & 0.036 & 0.038 & 0.045 & 0.043 & 0.049 & 0.045 & 0.052 & 0.054 & 0.051 & 0.052 & 0.056 & & 0.006 \\
\hline 17 & Hannoa_klaineana_\{Simaroubaceae\} & 0.047 & 0.047 & 0.043 & 0.036 & 0.034 & 0.037 & 0.028 & 0.030 & 0.033 & 0.041 & 0.020 & 0.020 & 0.017 & 0.034 & 0.020 & 0.053 & \\
\hline
\end{tabular}

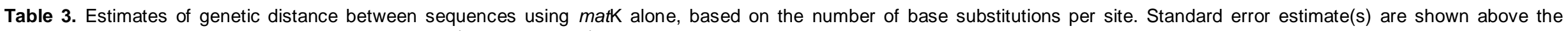
diagonal and were obtained by a bootstrap procedure (1000 replicates).

\begin{tabular}{|c|c|c|c|c|c|c|c|c|c|c|c|c|c|c|c|c|c|c|}
\hline & & \multicolumn{17}{|c|}{ Maturase K (matK) } \\
\hline & & 1 & 2 & 3 & 4 & 5 & 6 & 7 & 8 & 9 & 10 & 11 & 12 & 13 & 14 & 15 & 16 & 17 \\
\hline 1 & Melia_volkensii_\{Meliaceae\} & & 0.003 & 0.005 & 0.008 & 0.009 & 0.009 & 0.009 & 0.011 & 0.011 & 0.011 & 0.011 & 0.011 & 0.011 & 0.011 & 0.012 & 0.012 & 0.012 \\
\hline 2 & Melia_azedarach_\{Meliaceae\} & 0.015 & & 0.005 & 0.007 & 0.009 & 0.009 & 0.009 & 0.011 & 0.011 & 0.011 & 0.011 & 0.011 & 0.011 & 0.011 & 0.012 & 0.012 & 0.012 \\
\hline 3 & Azadirachta_indica_\{Meliaceae\} & 0.035 & 0.028 & & 0.008 & 0.008 & 0.009 & 0.009 & 0.011 & 0.011 & 0.011 & 0.011 & 0.011 & 0.011 & 0.011 & 0.012 & 0.011 & 0.012 \\
\hline 4 & Cipadessa_baccifera_\{Meliaceae\} & 0.060 & 0.054 & 0.055 & & 0.007 & 0.008 & 0.008 & 0.009 & 0.009 & 0.010 & 0.010 & 0.010 & 0.010 & 0.010 & 0.010 & 0.011 & 0.011 \\
\hline 5 & Toona_sinensis_\{Meliaceae\} & 0.064 & 0.062 & 0.059 & 0.046 & & 0.003 & 0.003 & 0.009 & 0.010 & 0.010 & 0.010 & 0.010 & 0.010 & 0.010 & 0.010 & 0.011 & 0.011 \\
\hline 6 & Swietenia_mahogani_\{Meliaceae\} & 0.067 & 0.064 & 0.062 & 0.051 & 0.010 & & 0.001 & 0.010 & 0.010 & 0.010 & 0.010 & 0.010 & 0.010 & 0.010 & 0.011 & 0.011 & 0.011 \\
\hline 7 & Swietenia_macrophylla_\{Meliaceae $\}$ & 0.069 & 0.065 & 0.063 & 0.052 & 0.011 & 0.003 & & 0.010 & 0.010 & 0.010 & 0.010 & 0.010 & 0.010 & 0.010 & 0.011 & 0.011 & 0.011 \\
\hline
\end{tabular}


Table 3. Contd.

\begin{tabular}{|c|c|c|c|c|c|c|c|c|c|c|c|c|c|c|c|c|c|c|}
\hline 8 & Picrasma_javanica_\{Simaroubaceae\} & 0.087 & 0.082 & 0.082 & 0.069 & 0.072 & 0.074 & 0.075 & & 0.002 & 0.007 & 0.007 & 0.007 & 0.006 & 0.007 & 0.009 & 0.008 & 0.008 \\
\hline 9 & Picrasma_quassioides_\{Simaroubaceae $\}$ & 0.088 & 0.083 & 0.083 & 0.070 & 0.072 & 0.075 & 0.075 & 0.004 & & 0.007 & 0.007 & 0.007 & 0.007 & 0.008 & 0.009 & 0.008 & 0.008 \\
\hline 10 & Ailanthus_triphysa_\{Simaroubaceae\} & 0.091 & 0.087 & 0.087 & 0.078 & 0.076 & 0.077 & 0.078 & 0.044 & 0.046 & & 0.004 & 0.008 & 0.004 & 0.006 & 0.010 & 0.009 & 0.006 \\
\hline 11 & Ailanthus_integrifolia_\{Simaroubaceae\} & 0.094 & 0.090 & 0.090 & 0.080 & 0.076 & 0.078 & 0.079 & 0.044 & 0.047 & 0.017 & & 0.008 & 0.004 & 0.006 & 0.010 & 0.009 & 0.006 \\
\hline 12 & Holacantha_emoryi_\{Simaroubaceae\} & 0.094 & 0.088 & 0.090 & 0.083 & 0.082 & 0.086 & 0.085 & 0.051 & 0.052 & 0.061 & 0.059 & & 0.008 & 0.008 & 0.010 & 0.004 & 0.009 \\
\hline 13 & Ailanthus_altissima_\{Simaroubaceae $\}$ & 0.094 & 0.090 & 0.089 & 0.078 & 0.074 & 0.076 & 0.076 & 0.044 & 0.046 & 0.017 & 0.017 & 0.058 & & 0.006 & 0.010 & 0.009 & 0.006 \\
\hline 14 & Nothospondias_staudtii_\{Simaroubaceae\} & 0.094 & 0.091 & 0.092 & 0.080 & 0.078 & 0.082 & 0.083 & 0.051 & 0.051 & 0.035 & 0.035 & 0.059 & 0.036 & & 0.010 & 0.008 & 0.006 \\
\hline 15 & Choisya_ternata_\{Rutaceae $\}$ & 0.094 & 0.087 & 0.089 & 0.081 & 0.077 & 0.081 & 0.082 & 0.072 & 0.071 & 0.079 & 0.080 & 0.082 & 0.080 & 0.080 & & 0.011 & 0.011 \\
\hline 16 & Castela_retusa_\{Simaroubaceae\} & 0.100 & 0.094 & 0.091 & 0.091 & 0.090 & 0.093 & 0.094 & 0.057 & 0.058 & 0.065 & 0.065 & 0.022 & 0.066 & 0.064 & 0.090 & & 0.010 \\
\hline 17 & Hannoa_klaineana_\{Simaroubaceae\} & 0.102 & 0.098 & 0.099 & 0.089 & 0.084 & 0.086 & 0.087 & 0.053 & 0.055 & 0.037 & 0.035 & 0.067 & 0.038 & 0.037 & 0.087 & 0.074 & \\
\hline
\end{tabular}

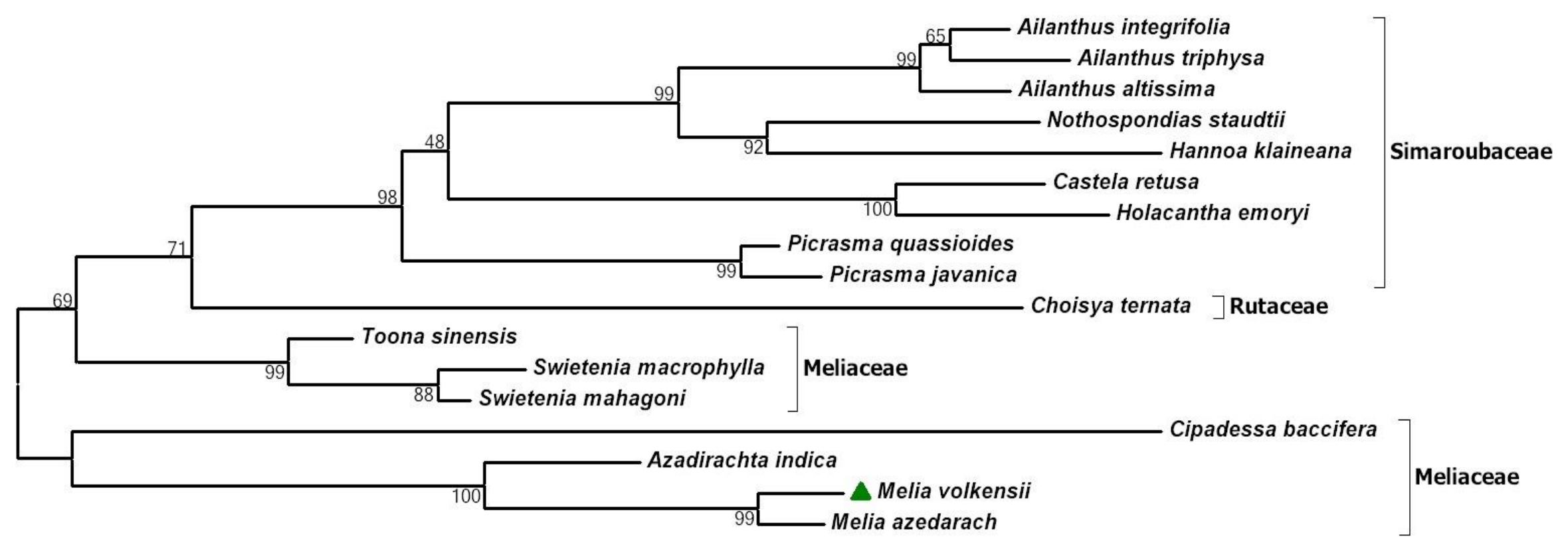

0.005

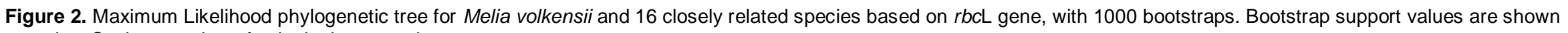
at nodes. Scale $=$ number of substitutions per site. 


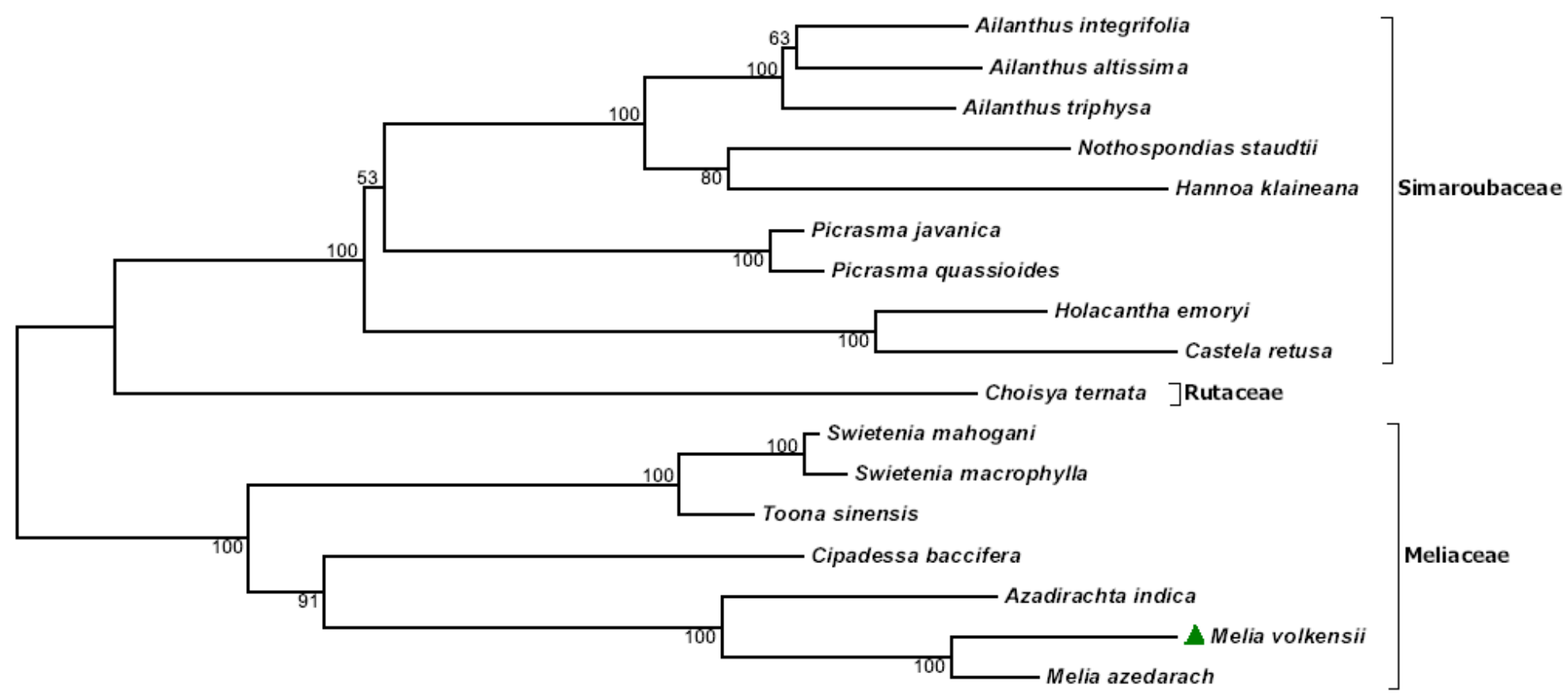

0.005

Figure 3. Maximum Likelihood phylogenetic tree for Melia volkensii and 16 closely related species based on matK gene, with 1000 bootstraps. Bootstrap support values are shown at nodes. Scale = number of substitutions per site.

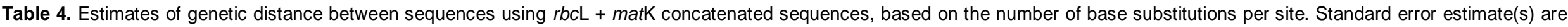
shown above the diagonal and were obtained by a bootstrap procedure (1000 replicates).

\begin{tabular}{|c|c|c|c|c|c|c|c|c|c|c|c|c|c|c|c|c|c|c|}
\hline & & \multicolumn{17}{|c|}{$r b c L+$ matK concatenated } \\
\hline & & 1 & 2 & 3 & 4 & 5 & 6 & 7 & 8 & 9 & 10 & 11 & 12 & 13 & 14 & 15 & 16 & 17 \\
\hline 1 & Melia_volkensii_\{Meliaceae\} & & 0.002 & 0.003 & 0.004 & 0.004 & 0.004 & 0.004 & 0.005 & 0.005 & 0.005 & 0.005 & 0.005 & 0.005 & 0.005 & 0.005 & 0.005 & 0.005 \\
\hline 2 & Melia_azedarach_\{Meliaceae\} & 0.010 & & 0.002 & 0.004 & 0.004 & 0.004 & 0.004 & 0.005 & 0.005 & 0.005 & 0.005 & 0.005 & 0.005 & 0.005 & 0.005 & 0.005 & 0.005 \\
\hline 3 & Azadirachta_indica_\{Meliaceae\} & 0.024 & 0.020 & & 0.004 & 0.004 & 0.004 & 0.004 & 0.005 & 0.005 & 0.005 & 0.005 & 0.005 & 0.005 & 0.005 & 0.005 & 0.005 & 0.005 \\
\hline 4 & Cipadessa_baccifera_\{Meliaceae\} & 0.052 & 0.049 & 0.047 & & 0.004 & 0.004 & 0.004 & 0.005 & 0.005 & 0.005 & 0.005 & 0.005 & 0.005 & 0.005 & 0.005 & 0.005 & 0.005 \\
\hline 5 & Toona_sinensis_\{Meliaceae\} & 0.046 & 0.045 & 0.042 & 0.041 & & 0.002 & 0.002 & 0.004 & 0.004 & 0.005 & 0.004 & 0.005 & 0.004 & 0.004 & 0.004 & 0.005 & 0.004 \\
\hline 6 & Swietenia_mahogani_\{Meliaceae\} & 0.049 & 0.048 & 0.045 & 0.045 & 0.008 & & 0.001 & 0.005 & 0.004 & 0.005 & 0.004 & 0.005 & 0.004 & 0.005 & 0.004 & 0.005 & 0.004 \\
\hline
\end{tabular}


Table 4. Contd.

\begin{tabular}{|c|c|c|c|c|c|c|c|c|c|c|c|c|c|c|c|c|c|c|}
\hline 7 & Swietenia_macrophylla_\{Meliaceae\} & 0.050 & 0.047 & 0.044 & 0.045 & 0.010 & 0.003 & & 0.005 & 0.005 & 0.005 & 0.004 & 0.005 & 0.005 & 0.004 & 0.004 & 0.005 & 0.004 \\
\hline 8 & Picrasma_javanica_\{Simaroubaceae\} & 0.063 & 0.061 & 0.059 & 0.056 & 0.049 & 0.051 & 0.051 & & 0.001 & 0.004 & 0.004 & 0.004 & 0.003 & 0.004 & 0.004 & 0.004 & 0.004 \\
\hline 9 & Picrasma_quassioides_\{Simaroubaceae $\}$ & 0.063 & 0.061 & 0.059 & 0.058 & 0.050 & 0.052 & 0.052 & 0.004 & & 0.004 & 0.004 & 0.004 & 0.003 & 0.004 & 0.004 & 0.004 & 0.004 \\
\hline 10 & Ailanthus_triphysa_\{Simaroubaceae $\}$ & 0.068 & 0.066 & 0.064 & 0.067 & 0.055 & 0.057 & 0.057 & 0.035 & 0.036 & & 0.002 & 0.004 & 0.002 & 0.003 & 0.004 & 0.004 & 0.003 \\
\hline 11 & Ailanthus_integrifolia_\{Simaroubaceae\} & 0.068 & 0.066 & 0.065 & 0.066 & 0.054 & 0.056 & 0.056 & 0.034 & 0.035 & 0.011 & & 0.004 & 0.002 & 0.003 & 0.004 & 0.004 & 0.003 \\
\hline 12 & Holacantha_emoryi_\{Simaroubaceae\} & 0.069 & 0.065 & 0.066 & 0.068 & 0.058 & 0.061 & 0.060 & 0.040 & 0.039 & 0.046 & 0.044 & & 0.004 & 0.004 & 0.005 & 0.003 & 0.004 \\
\hline 13 & Ailanthus_altissima_\{Simaroubaceae\} & 0.068 & 0.066 & 0.065 & 0.066 & 0.053 & 0.055 & 0.055 & 0.034 & 0.035 & 0.012 & 0.011 & 0.044 & & 0.003 & 0.005 & 0.004 & 0.003 \\
\hline 14 & Nothospondias_staudtii_\{Simaroubaceae\} & 0.068 & 0.066 & 0.064 & 0.066 & 0.055 & 0.058 & 0.058 & 0.038 & 0.038 & 0.027 & 0.027 & 0.044 & 0.027 & & 0.004 & 0.004 & 0.003 \\
\hline 15 & Choisya_ternata_\{Rutaceae $\}$ & 0.069 & 0.064 & 0.065 & 0.063 & 0.054 & 0.057 & 0.056 & 0.054 & 0.053 & 0.060 & 0.059 & 0.062 & 0.060 & 0.060 & & 0.005 & 0.004 \\
\hline 16 & Castela_retusa_\{Simaroubaceae $\}$ & 0.070 & 0.068 & 0.066 & 0.070 & 0.061 & 0.064 & 0.064 & 0.041 & 0.041 & 0.049 & 0.047 & 0.016 & 0.048 & 0.047 & 0.066 & & 0.004 \\
\hline 17 & Hannoa_klaineana_\{Simaroubaceae\} & 0.075 & 0.073 & 0.071 & 0.072 & 0.060 & 0.062 & 0.062 & 0.041 & 0.042 & 0.029 & 0.028 & 0.051 & 0.029 & 0.027 & 0.065 & 0.054 & \\
\hline
\end{tabular}

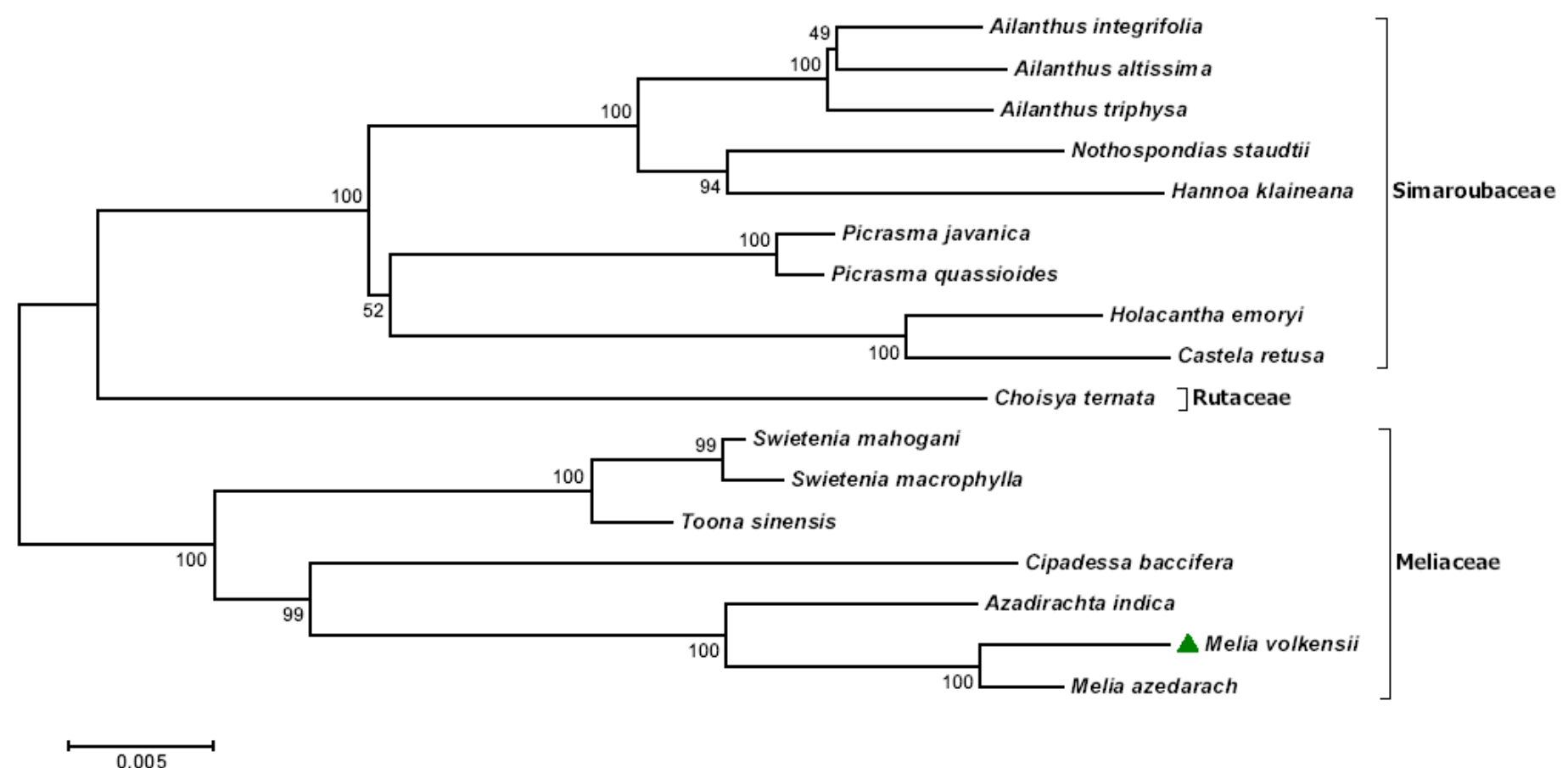

Figure 4. Maximum Likelihood phylogenetic tree for Melia volkensii and 16 closely related species based on rbcL + matK concatenated genes, with 1000 bootstraps. Bootstrap support values are shown at nodes. Scale = number of substitutions per site. 


\section{REFERENCES}

Barthet MM, Hilu KW (2007). Expression of matK: functional and evolutionary implications. Am. J. Bot. 94(8):1402-1412.

CBOL Plant Working Group (2009). A DNA barcoding for land plants. Proc. Natl. Acad. Sci. USA. 106(31):12794-12797.

Doyle JJ, Doyle JL (1987). A rapid DNA isolation procedure for small quantities of fresh leaf tissue. Phytochem. Bull. 19:11-15.

Edgar RC (2004). MUSCLE: multiple sequence alignment with high accuracy and high throughput. Nucleic Acids Res. 32(5):1792-1797.

Fay MF, Bayer C, Alverson WS, De Bruijn AY, Chase MW (1998). Plastid rbcL sequence data indicate a close affinity between Diegodendron and Bixa. Taxon 47:43-50.

Fazekas AJ, Kuzmina ML, Newmaster SG, Hollingsworth PM (2012). DNA barcoding methods for land plants. In: DNA barcodes. Humana Press. pp. 223-252.

Felsenstein J (1985). Confidence limits on phylogenies: An approach using the bootstrap. Evolution 39:783-791.

Ferri G, Alu M, Corradini B, Angot A, Beduschi G (2008). Land plants identification in forensic botany: multigene barcoding approach. Forensic Sci. Int. (Genetics Supplement Series) 1(1):593-595.

Ferri G, Corradini B, Ferrari F, Santunione AL, Palazzoli F, Alu' M (2015). Forensic botany II, DNA barcode for land plants: Which markers after the international agreement? Forensic Sci. Int. Genet. $15: 131-136$

Hausner G, Olson R, Simon D, Johnson I, Snaders ER, Karol KG, McCourt RM, Zimmerly S (2006). Origin and evolution of the chloroplast trnk (matK) intron: A model for evolution of group II intron RNA structures. Mol. Biol. Evol. 23(2):380-391.

Hebert PDN, Cywinska A, Ball SL, DeWaard JR (2003) Biological identification through DNA barcodes. Proc. Soc. Lond. B Biol. 270:313-321.

Hilu KW, Liang H (1997). The matK gene: sequence variation and application in plant systematics. Am. J. Bot. 84:830-839.

Hollingsworth PM, Graham SW, Little DP (2011). Choosing and Using a Plant DNA Barcode. PLoS ONE 6(5):e19254.

Johnson LA, Soltis DE (1994). matK DNA sequences and phylogenetic reconstruction in Saxifragaceae s. str. Syst. Bot. 19:143-156.

Kress WJ, Erickson DL, Jones FA, Swenson NG, Perez R, Sanjur O, Bermingham E (2009). Plant DNA barcodes and a community phylogeny of a tropical forest dynamics plot in Panama. Proc. Natl. Acad. Sci. USA. 106(44):18621-6.

Kress WJ, Garcia-Robledo C, Uriarte M, Erickson DL (2015). DNA barcodes for ecology, evolution, and conservation. Trends Ecol. Evolut. 30(1):25-35.

Kress WJ, Wurdack KJ Zimmer EA, Weigt L A, Janzen DH (2005). Use of DNA barcodes to identify flowering plants. Proc. Natl. Acad. Sci. USA. 102(23):8369-8374.

Kritpetcharat $\mathrm{O}$, Khemtonglang N, Kritpetcharat $\mathrm{P}$, Daduang J, Daduang S, Suwanrungruang K, Bletter N, Sudmoon R, Chaveerach A (2011). Using DNA markers and barcoding to solve the common problem of identifying dried medicinal plants with the examples of Smilax and Cissus in Thailand. J. Med. Plants Res. 5(15):3480-3487.
Kuzmina ML, Johnson KL, Barron HR, Hebert PDN (2012). Identification of the vascular plants of Churchill, Manitoba, using a DNA barcode library. BMC Ecol. 12:25.

Li, FW, Kuo LY, Rothfels CJ, Ebihara A, Chiou WL, Windham MD, Pryer KM (2011). rbcL and matK Earn Two Thumbs Up as the Core DNA Barcode for Ferns. PLoS ONE 6(10):e26597.

Mankga LT, Yessoufou K, Moteetee AM, Daru BH, van der Bank M (2013). Efficacy of the core DNA barcodes in identifying processed and poorly conserved plant materials commonly used in South African traditional medicine. ZooKeys 365:215-233.

Mishra P, Kumar Amit, Nagireddy A, Mani DN, Shukla AK, Tiwari R, Sundaresan V (2016). DNA barcoding: an efficient tool to overcome authentication challenges in the herbal market. Plant Biotechnol. J. 14:8-21

Nei M, Kumar S (2000). Molecular Evolution and Phylogenetics. Oxford University Press, New York.

Newmaster SG, Ragupathy S (2009). Ethnobotany genomics - use of DNA barcoding to explore cryptic diversity in economically important plants. Indian J. Sci. Technol. 2(5):1-8.

Orwa C, Mutua A, Kindt R, Jamnadass R, Simons A (2009). Agroforestree Database: a tree reference and selection guide version 4.0, World Agroforestry Centre, Kenya. http://www.worldagroforestry.org/af/treedb/.

Rambaut A (2012). FigTree 1.4. FigTree: Tree Figure Drawing Tool Version 1.4. Edinburgh, Scotland: University of Edinburgh.

Rohwer JG (2000). Towards a phylogenetic classification of the Lauraceae; Evidence from matK sequences. Syst. Bot. 25(1):60-71.

Steane DA (2005). Complete nucleotide sequence of the chloroplast genome from the Tasmanian blue gum, Eucalyptus globulus (Myrtaceae). DNA Res. 12:215-220.

Tamura K, Stecher G, Peterson D, Filipski A, Kumar S (2013). MEGA6: Molecular Evolutionary Genetics Analysis version 6.0. Mol. Biol. Evol. 30(12):2725-2729.

Vijayan K, Tsou CH (2015). DNA barcoding in plants: taxonomy in a new perspective. Curr. Sci. 99(11):1530-1541.

Vogel J, Hübschmann T, Börner T, Hess WR (1997). Splicing and intron internal RNA editing of trnK-matK transcripts in barley plastids: support for matK as an essential splice factor. J. Mol. Biol. 270:179187.

Wiart C (2006). Medicinal plants of the Asia-Pacific: Drugs for the future? World Scientific Publishing Co. Ltd., Singapore. 